\title{
Conservation of Electrical Energy in the Residential Buildings using Simple Practices
}

\author{
Piyushkumar M. Saradva \\ Electrical Engineering Department, Government Polytechnic, Rajkot \\ Email: pmsaradva@gmail.com
}

\begin{abstract}
Electrical energy has become a primary need for any individual in India. The persons lining at the residential buildings utilize the electrical energy supplied to them by the distribution companies. Based on the amount of electrical energy consumed by them, they need to pay the charge in form of the electricity bill. There are many direct and indirect disadvantages of consuming more electrical energy. It is observed that there are many opportunities to conserve the electrical energy in the residential buildings. If electrical energy is conserved then there would be many direct and indirect advantages. In this paper simple practices have been suggested following which, electrical energy can be conserved in the residential buildings and hence many advantages can be obtained.
\end{abstract}

Index Terms- Electrical Energy, Electricity, Residential buildings, Conservation, Home appliances, Practices

\section{INTRODUCTION ${ }^{1-6}$}

The use of electrical energy has been increasing each and every day in India. It is difficult to imagine the life of people in India without electricity because the large no. of electrical and electronic home appliances and other devices in their houses can be run using electrical energy only.

To avail the electricity, the people living at the residential buildings need to have an electricity connection form the electrical power distribution company. Through this connection, they can utilize the electrical energy when needed to run the different devices and home appliances at their houses. Based on the amount of electrical energy utilized by them, they need to pay the charge in form of the electricity bill.

\subsection{Disadvantage of consuming more electrical energy for the consumers}

For the point of view of the consumers higher is the consumption of electrical energy, higher would be the electricity bill, they will have to pay.

\subsection{Other Disadvantage of using more electrical energy}

- In order to meet the higher demand of electrical energy of the consumers, the more electrical energy must be generated. To meet this additional demand, the more no. of power generating stations must be established. This causes economical burden on the country. Since generating stations need large amount of land, this may result in environmental and social problems also.

- The efficiency of the generating stations and the transmission and distribution lines is low. So, in

the activities get done when the day light is order to meet the demand of electrical energy, the electrical energy to be generated at the generating stations must be even more. It has been observed that that to meet a demand of $1 \mathrm{kWh}$ of electrical energy, the electrical energy to be generated must be $>1.6 \mathrm{kWh}$.

- Since most of the Power generating stations in India are of conventional type, more amount of exhaustible fuel like coal etc. has to be utilized.

- Burning of fuel in the generation station would create more pollution.

\section{NEED OF CONSERVATION OF ELECTRICAL ENERGY IN THE RESIDENTIAL BUILDINGS ${ }^{1,4-6}$}

The large amount of electrical energy is consumed in the residential buildings only. The disadvantages of the higher consumption of electrical energy have been discussed above. In order to reduce the effect of these disadvantages, the only option available is to conserve the electrical energy in the residential buildings.

\section{SIMPLE PRACTICISES FOR CONSERVATION OF ELECTRICAL ENERGY IN THE RESIDENTIAL BUILDINGS $^{1,4-6}$}

Here, some simple steps have been suggested, following which a large amount of electrical energy can be conserved at the residential buildings.

1. Design and construct the residential buildings in such a way that the natural resources like sun and wind can be utilized as much as possible so as to reduce the use of lights, fans, air -conditioners, room heaters etc.

2. Utilize day light as much as possible. Schedule your daily activities in a such a way that most of available

3. Make habit of switching off all the devices and 
appliances, when they are not in use.

4. Use the more efficient CFL and LED lamps instead of using the incandescent lamps. Also design your lighting system, so as either less no. of light sources or light sources with less power ratings are needed.

5. Use Solar Water Heater to have the hot water instead of using the electrical heater and geysers.

6. Use Energy Efficient home appliances. The appliances having more star ratings consume less electrical energy.

7. If possible do not use or reduce the use of the electrical /electronic home appliances like washing machine, air-conditioners ,lifts, room heaters Induction cook-tops, mixer-grinders etc.

8. Use the latest technology like automatic lighting system, automatic water level controller etc. to reduce the waste of electrical energy.

9. If possible utilize solar panels (solar roof top system) to generate the electrical energy at your residential buildings.

\section{NUMRICAL ANALYSIS OF THE POSSIBLE BENEFITS}

Following the simple practices mentioned above, a large amount of electrical energy can be conserved in the residential buildings. The calculation of electrical energy possible to be conserved in India due this has been shown in Table 1.

Table 1. Calculation of Possible Conservation of Electrical energy

\begin{tabular}{|c|c|c|}
\hline $\begin{array}{c}\text { No. of } \\
\text { Houses }\end{array}$ & $\begin{array}{c}\text { Possible } \\
\text { conservation of } \\
\text { electrical } \\
\text { energy/Month/ } \\
\text { House }\end{array}$ & $\begin{array}{c}\text { Total Possible } \\
\text { Energy } \\
\text { Conservation } \\
\text { /Month }\end{array}$ \\
\hline $244688900^{7,8}$ & $10 \mathrm{kWh}$ & $\begin{array}{l}2446889000 \\
\mathrm{kWh}\end{array}$ \\
\hline
\end{tabular}

\section{CONCLUSION}

The increasing use of electrical energy in residential buildings in India may cause many serious issues. By using the practices discussed in this paper which are easy to follow at the residential buildings a large amount of electrical energy can be conserved and due to this many benefits can be achieved.

\section{Acknowledgments}

Author is thankful to all his colleagues for motivating him to write this paper.

\section{REFERENCES}

[1] R.P. Ajwalia (2016) : Energy Conservation \& Audir, Atul Prakashan

[2] J.B.Gupta, Rajeev Manglik, Rohit Manglik: Utilization of Electrical Energy and Traction",
S.K. Kataria \& Sons Publication

[3] J.B.Gupta (2003) : Utilization of Electric Power \& Electric Traction, S.K. Kataria \& Sons Publication

[4] Dr. V. Thiyagarajan: Electric Energy Generation Utilization And Conservation, Laxmi Publications

[5] Prof. Sunil S. Rao, Utilization, Generation \& Conservation of Electrical Energy, Khanna Publications

[6] S. Sivanagaraju , M. Balasubba Reddy , D. Srilatha (2011) : Electric Energy: Generation, Utilization and Conservation, Pearson Publication

[7] http://mospi.nic.in/statistical-year-bookindia/2017/197

[8] http://www.censusindia.gov.in 